\title{
Role of folate dependent transformylases in synthesis of purine in bone marrow of man and in bone marrow and liver of rats
}

\author{
ROSEMARY DEACON, I CHANARIN, M LUMB, JANET PERRY \\ From the Haematology Section, Medical Research Council Clinical Research Centre, Harrow, Middlesex
}

SUMMARY The activity of the two folate dependent enzymes supplying carbon 2 and carbon 8 of the purine nucleus was assayed in the bone marrow of rats and man, as well as in rat livers. The activity of both enzymes was several fold greater in marrow than in liver. Inactivation of cobalamin by exposure to nitrous oxide did not affect the enzymes in rat marrow cells, although an appreciable effect on hepatic enzymes was found. The depression of hepatic glycinamide ribotide (GAR) transformylase in rats exposed to nitrous oxide was prevented by supplying a formate precursor, methylthioadenosine. There was a considerable rise in the activity of GAR transformylase in human marrow cells from patients with megaloblastic anaemia due to cobalamin deficiency but no change in activity in marrow from patients deficient in folate.

In 1958 Lajtha and Vane suggested that the liver was the principal site of purine synthesis. ${ }^{1}$ Furthermore, they suggested that the purines required for DNA synthesis by marrow cells were imported from the liver whereas pyrimidine (thymidine), also required for DNA, was independently synthesised in the marrow. This deduction was based on the DNA labelling of marrow cells with $\left({ }^{14} \mathrm{C}\right)$ formate. When $\left({ }^{14} \mathrm{C}\right)$ formate was given to an intact rabbit the label appeared in both marrow purine and thymidine: when it was given to a rabbit that had had its liver removed marrow thymidine only was labelled. More recently, however, despite some contrary data independent purine synthesis has been shown in man in peripheral blood leucocytes, ${ }^{2}$ in lymphocytes in marrow mononuclear cells, ${ }^{3-5}$ and in a promyelocytic cell line. ${ }^{6}$

Folate has a key role in purine synthesis, contributing carbons 2 and 8 to the purine nucleus. Carbon 8 is inserted by the enzyme glycinamide ribotide (GAR) transformylase (EC 2.1.2.2.) and carbon 2 by the enzyme 5-amino-4-imidazole carboxamide (AICAR) transformylase (EC 2.1.2.3.). With each enzyme the formyl donor is 10-formyltetrahydrofolatepolyglutamate. $^{7}$

The purpose of this study was to assess the activity of these two folate dependent enzymes in both liver and marrow of rats breathing air or breathing $50 \%$ nitrous oxide, which activates cob(I)alamin and hence inactivates the enzyme methionine synthetase. This in turn has profound effects on the metabolism of folate. ${ }^{8}$ The activity of these enzymes was also measured in samples of marrow from normoblastic and megaloblastic patients.

\section{Material and methods}

Bone marrow samples were available from 10 patients who required marrow aspiration for clinical purposes. Four patients had normoblastic haemopoiesis and were haematologically normal. Six had a macrocytic anaemia, and the marrow was megaloblastic in all. One patient had pernicious anaemia, two were Hindu vegetarians with nutritional cobalamin deficiency, one was taking anticonvulsants and had folate deficiency, and two had nutritional folate deficiency (combined alcoholism in one). The haemoglobin concentrations in the megaloblastic patients with cobalamin deficiency were $5 \cdot 1,7 \cdot 3$, and $10 \cdot 5 \mathrm{~g} / \mathrm{dl}$, respectively, and in those with folate deficiency $5 \cdot 5,7 \cdot 1$, and $12 \cdot 5$ $\mathrm{g} / \mathrm{dl}$ respectively. The patients deficient in cobalamin had low serum cobalamin concentrations and normal red cell folate concentrations. Those deficient in folate had normal serum cobalamin and low red cell folate concentrations.

Male Sprague-Dawley rats weighing 80-100 g were used. Exposure to nitrous oxide and oxygen, $(1 / 1, v / v)$ 
took place in a perspex chamber through which a mixture of the gases was passed; carbon dioxide and humidity were controlled. An unrestricted supply of water and food was given. Control rats breathed air.

\section{PREPARATION OF EXTRACTS}

Livers were homogenised in cold $0.03 \mathrm{M}$ potassium phosphate buffer, $\mathrm{pH} 7 \cdot 0$. Homogenates (about 50 $\mathrm{mg} / \mathrm{ml}$ ) were then centrifuged at $3000 \mathrm{~g}$ for 45 minutes at $4^{\circ} \mathrm{C}$.

Samples of human marrow were taken into $10 \mathrm{ml}$ cold Hanks's balanced salt solution (containing 1000 IU heparin). Red cells were lysed with distilled water and an equal volume of $1.8 \%$ sodium chloride was added.

Rat marrows were taken into cold phosphate buffered saline and processed as described for human marrow. Cell pellets from human and rat marrows were washed twice with cold PBSA and finally suspended in about $1 \mathrm{ml}$ cold $0.03 \mathrm{M}$ potassium phos-

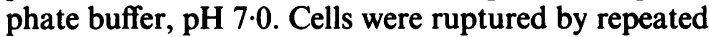
freezing and thawing and centrifuged at $3000 \mathrm{~g}$ for 45 minutes at $4^{\circ} \mathrm{C}$.

GAR was synthesised from $1-{ }^{14} \mathrm{C}$ ]glycine. GAR was incubated with the tissue being assayed and 5,10-methenylH ${ }_{4}$ PteGlu. Formyl (methenyl) transfer was assessed by measuring residual $\mathrm{H}_{4}$ PteGlu in the reaction mixture, as described elsewhere. ${ }^{9-11}$

AICAR was incubated with the tissue being assayed and 10 -formylH ${ }_{4}$ PteGlu. Residual AICAR that had not been converted into inosinic acid was assayed by the Bratton-Marshall procedure, as described elsewhere. ${ }^{9-11}$

Results were analysed using the Sheffe procedure for multiple comparison of means modified to take account of the non-homogenous variances found. ${ }^{12}$ In addition, comparison of data on individual days was carried out using Student's $t$ test.

\section{Results}

\section{COMPARISON OF ENZYME ACTIVITY IN RAT} LIVER AND MARROW

Fig. 1 shows the activity of enzymes that synthesise purine both in the liver and marrow from healthy Sprague-Dawley rats. AICAR transformylase and GAR transformylase showed four fold and seven fold greater activity, respectively, in marrow than in liver (Fig. 1). The mean value for GAR transformylase activity in 60 rat livers was 1.27 (SD 0.47) $\mathrm{nmol}$ $\mathrm{H}_{4} \mathrm{PteGlu}$ formed/mg protein and the corresponding value for 20 samples of marrow was 9.07 (2.15). The mean AICAR transformylase activity in $\mathbf{4 5}$ rat livers was $7.71(1.87) \mathrm{nmol}$ AICAR used/mg protein. The corresponding value for rat marrow was $33 \cdot 55(6 \cdot 12)$.

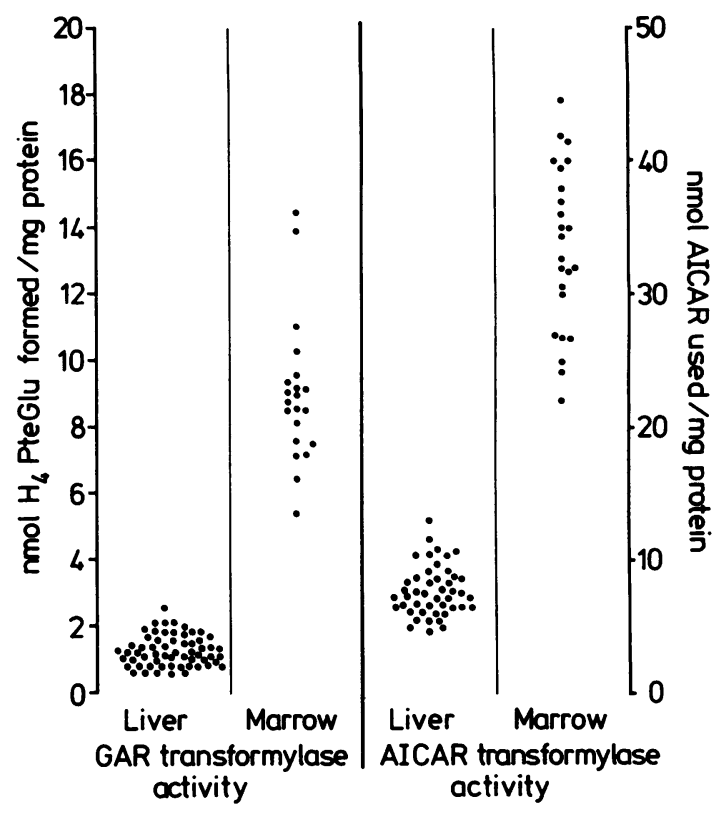

Fig. 1 Comparison of activity of the two folate dependent transformylases in purine synthesis in rat liver and marrow.

EFFECT OF INACTIVATION OF COBALAMIN ON
ENZYME ACTIVITY

There was no important change in GAR transformylase activity in marrow after five days of exposure to nitrous oxide. This contrasts with the results found in the liver: a considerable drop in activity occurred 24 hours after exposure (Fig. 2). ${ }^{9}$

There was no important overall trend in AICAR transformylase activity in marrow on exposure to nitrous oxide. The values on day 3 of exposure were significantly lower than in controls $(p=0.02)$. The same enzyme in liver showed a significant increase in activity on exposure to nitrous oxide. ${ }^{9}$

Enzyme activity in marrow in man The activity of GAR transformylase in the three marrows deficient in 0 cobalamin was significantly higher than in controls $(p=0.01)$ and higher than that in the folate deficient $\frac{T}{O}$ group (Fig. 3). There were no differences in AICAR transformylase activity between normoblastic and $\widetilde{N}$ megaloblastic human marrows.

EFFECT OF METHIONINE AND METHYLTHIOADENOSINE ON GAR

TRANSFORMYLASE IN THE RAT

The fall in GAR transformylase activity after four days of exposure to nitrous oxide was assumed to be due to a failure in the supply of single carbon units at the formate level of oxidation. These are normally $\bar{D}$ 


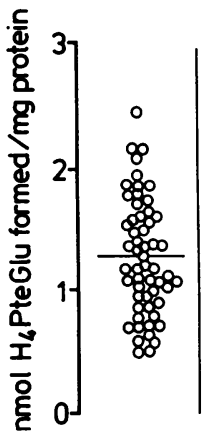

GAR transtormylase activity.

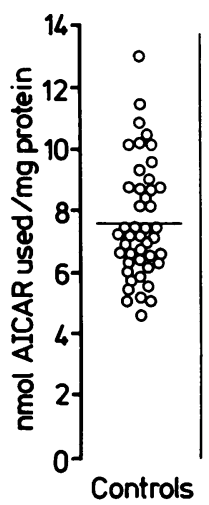

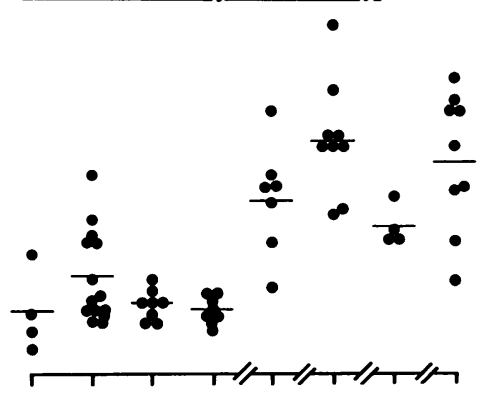

AICAR transformylase activity

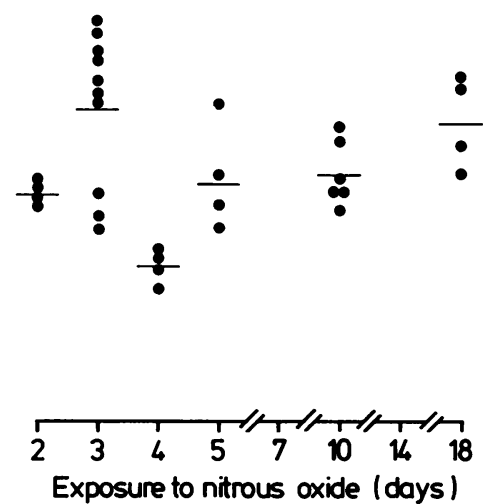

Fig. 2 Effect of inactivation of cobalamin by exposure to nitrous oxide on activity of the two folate dependent transformylase activities in purine synthesis in rat liver.

derived from methionine, and 5'methylthioadenosine is an intermediary in the pathway to formate. ${ }^{13}$ Rats were therefore exposed to nitrous oxide, and one group given methionine ( $16 \mathrm{nmol}$ daily) and methylthioadenosine (16 nmol daily) and a third group served as control. Methionine had no effect on preventing the fall in rat liver GAR transformylase activity, but this was prevented by methylthioadenosine (Table).

\section{Discussion}

The activity of the two folate dependent transformylases in the marrow has not been assayed previously. The results showed that considerably more activity occurred in marrow than in liver and leave little doubt that marrow is an active site of independent purine synthesis. Although purine synthesis in the liver is largely concerned with turnover of purine nucleotides in intermediary metabolism (NADH, ATP, FAD), as well as for RNA, in marrow the greater requirement is for provision of adenine and guanine for DNA and RNA.

Nitrous oxide has less effect on GAR trans-

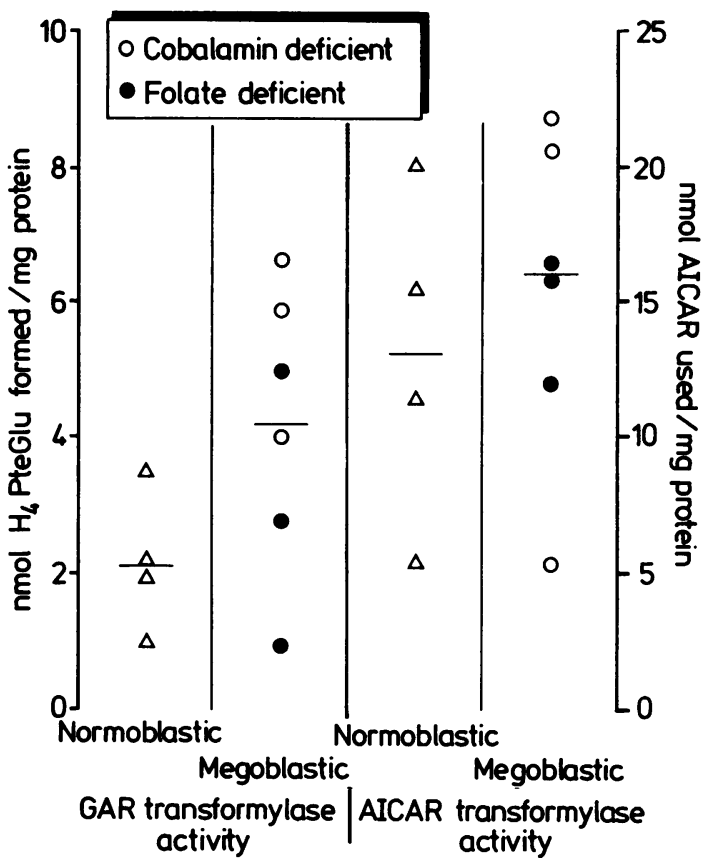

Fig. 3 Activity of the two folate dependent transformylases in purine synthesis in human marrow from normoblastic patients $(\Delta)$, megaloblastic patients with cobalamin deficiency $(\mathrm{O})$, and megaloblastic patients with folate deficiency $(\mathbf{O})$.

formylase activity in marrow than in liver and, unlike liver, no effect on marrow AICAR transformylase activity. The effect of nitrous oxide on purine synthesis is to curtail the supply of formate needed both for $\mathrm{C} 2$ and $\mathrm{C} 8$ of the purine nucleus supplied via methionine. ${ }^{14}$ The less potent effect of nitrous oxide in marrow cells suggests that sources of formate other than methionine are more readily available in marrow than in liver. These sources are presumably independent of cobalamin and folate. Furthermore, the activ-

$G A R$ transformylase activity in rat liver ( $\mathrm{nmol} \mathrm{H}_{4} \mathrm{PteGlu}$ formed/mg protein) and effect of methionine and methylthioadenosine (MTA)

\begin{tabular}{ll}
\hline Exposure (days) & $\begin{array}{l}\text { Mean GAR transformylase } \\
\text { activity }(S D)\end{array}$ \\
\hline Control $(\mathrm{n}=7)$ & $1.57(0.38)$ \\
$\mathrm{N}_{2} \mathrm{O}:$ & $\begin{array}{l}0.74(0.37)^{*} \\
\text { Four days }(\mathrm{n}=3)\end{array}$ \\
Four days and methionine $(\mathrm{n}=4)$ & $\begin{array}{l}0.6(0.26) \dagger \\
1.37(0.5) \ddagger\end{array}$ \\
Four days and MTA $(\mathrm{n}=4)$ & $1.37(0.5) \dagger$
\end{tabular}

*Significantly less than control $(p=0.01)$.

tSignificantly less than control $(\mathrm{p}=0.001)$.

$\ddagger$ No significant difference from control. 
ity of methionine synthetase in marrow is very low compared to that in liver and difficult to assay by conventional methods, once again suggesting that methionine may not be the major supplier of formate to marrow. ${ }^{15}$ Nevertheless, the effect of methylthioadenosine, which is derived from methionine and is a precursor of formate, in preventing a fall in GAR transformylase in the livers of rats treated with nitrous oxide still indicates that methionine is a supplier of formate units.

Many enzymes show increased activity in megaloblastic anaemia in man, ${ }^{16}$ and these are increased equally both in folate and cobalamin deficiency. It is unusual to find the increase in only cobalamin deficiency, as occurred in GAR transformylase activity. It is tempting to suggest that this is a response to a lack of formyl units required for GAR transformylase activity, which are normally derived from methionine.

\section{References}

${ }^{1}$ Lajtha LG, Vane JR. Dependence of bone marrow cells in the liver for purine supply. Nature 1958;182:191-2.

${ }^{2}$ Brosh G, Boer P, Kupfer B, De Vries A, Sperling O. De novo synthesis of purine nucleotides in human peripheral blood leukocytes. Excessive activity of the pathway in hypoxanthine-guanine phosphoribosyltransferase deficiency. J Clin Invest 1976; 58:289-97.

${ }^{3}$ Gordon RB, Counsilman AC, Cross SMC, Emmerson BT. Purine synthesis de novo in lymphocytes from patients with gout. Clin Sci 1982;63:429-35.

${ }^{4}$ Peters GJ, Veerkamp JH. Purine and pyrimidine metabolism in peripheral blood lymphocytes. Int J Biochem 1983;1:115-23.

${ }^{5}$ McCairns E, Fahey D, Sauer D, Rowe PB. De novo purine synthesis in human lymphocytes. $J$ Biol Chem 1983;258:1851-6.

${ }^{6} \mathrm{King}$ ME, Honeysett JM, Howell SB. Regulation of de novo purine synthesis in human bone marrow mononuclear cells by hypoxanthine. J Clin Invest 1983;72:965-70.

${ }^{7}$ Smith GK, Mueller WT, Slieker LJ, DeBrosse CW, Benkovic SJ. Direct transfer of one-carbon unit in the transformylations of de novo purine biosynthesis. Biochemistry 1982;21:2870-4.

${ }^{8}$ Chanarin I. Cobalamins and nitrous oxide: a review. J Clin Pathol 1981;33:909-16.

${ }^{9}$ Deacon R, Perry J, Lumb M, Chanarin I. Effect of nitrous oxideinduced inactivation of vitamin B12 on glycinamide ribonucleotide transformylase and 5-amino-4-imidazole carboxamide transformylase. Biochem Biophys Res Comm 1983; 112:327-31.

${ }^{10}$ Deacon R, Perry J, Lumb M, Chanarin I. Effect of cobalamin inactivation on folate-dependent transformylase involved in purine synthesis in rats. Biochem $J$ 1985;227:67-71.

${ }^{11}$ Flaks J, Lukens L. The enzymes of purine nucleotide synthesis de novo. In: Colowick SD, Kaplan NO, eds. Methods in enzymology. Academic Press: New York, 1963:52-95.

${ }^{12}$ Gill JL. Design and analysis of experiments in the animal and medical sciences. 1. Iowa: Iowa State Universities Press, 1978:177-9.

${ }^{13}$ Trackman PC, Abeles RM. The metabolism of 1-phospho-5methylthioribose. Biochem Biophys Res Comm 1981;163: 1238-44.

${ }^{14}$ Perry J, Chanarin I, Deacon R, Lumb M. Chronic cobalamin inactivation impairs folate polyglutamate synthesis in the rat. $J$ Clin Invest 1983;71:1183-90.

${ }^{15}$ Taylor RT, Hanna ML, Hutton JJ. 5-methyl-tetrahydrofolate homocysteine cobalamin methyltransferase in human bone marrow and its relationship to pernicious anemia. Arch Biochem Biophys 1974;165:787-95.

${ }^{16}$ Chanarin I. The megaloblastic anaemias, 2nd ed. Blackwelf Scientific Publications: Oxford, 1979:255-8.

Requests for reprints to: Dr I Chanarin, Consultant Haematologist, Northwick Park Hospital, Watford Road, Harrow, Middlesex HAl 3UJ, England. 